\title{
THE IMPACT OF EU LAW ON PRIVATE LAW - SOME THOUGHTS ON THE IMPACT OF THE NON-DISCRIMINATION PRINCIPLE ON PRIVATE AUTONOMY
}

Norbert Reich*

n.reich1@gmx.net

Recebido em 25/03/2013

Aprovado em 28/06/2013

\begin{abstract}
The paper discusses a new dimension of EU law, namely its impact on private law based on the principle of non-discrimination, thus deliberately going beyond concepts of autonomy and freedom of contract as recognised in all Member States and by the EU itself. Article 21 of the EU Charter of Fundamental Rights has "constitutionalised" this principle which originally found recognition in several EU directives on employment and consumer law analysed in this paper with a special regard to the growing case-law of the Court of Justice of the EU (ECJ).
\end{abstract}

\section{Keywords}

Principle of Non-discrimination; EU Charter of Fundamental Rights; Party Autonomy; Civil Law Remedies.

* Emeritus Professor, University of Bremen, Faculty of Law, e-mail n.reich1@gmx.net. The paper continues earlier reflections in: REICH, N. The public/private divide in European law, in: CAFAGGI/MICKLITZ (ed.), After the Common Frame of Reference, 2010, pp. 56; same: "The Social, Political and Cultural Dimension of EU Private Law", in: R. SCHULZE (ed.), European Private Law - Current Status and Perspectives 2011, pp. 57; same: "Pluralism and Private Law in the Union", in: L. NIGLIA (ed.), Pluralism and European Private Law, 2013, pp. 73; same, The Impact of the Non-Discrimination Principle on Private Autonomy, in: D. Leczykiewicz/St. Weatherill (eds.), The Involvement of EU Law in Private Relationships, 2013 , pp. 252. 


\title{
O IMPACTO DA LEGISLAÇÃO DE DIREITO PRIVADO NOS ESTADOS UNIDOS DA AMÉRICA - ALGUNS \\ PENSAMENTOS DE IMPACTO DO PRINCÍPIO DA NÃO DISCRIMINAÇÃO NA AUTONOMIA PRIVADA
}

\author{
Norbert Reich
}

\section{Resumo}

Este papel discute a nova dimensão do direito europeu, a saber, o seu impacto no direito privado, baseado no princípio da não discriminação, além de deliberadamente ir além dos conceitos de autonomia e liberdade contratual como reconhecidos pelos países membros e pela própria União Europeia. O artigo 21 da Carta dos Direitos Fundamentais da União Europeia “constitucionalizou” este princípio que originalmente encontrou seu reconhecimento em muitas diretivas da
União europeia sobre trabalho e direito do consumidor, é analisado neste paper com especial atenção ao aumento dos casos no Tribunal de Justiça da União Europeia (ECJ).

\section{Palavras-Chave}

Princípio da Não-discriminação; Carta dos Direitos Fundamentais da União Europeia; Autonomia da Parte; Remédios do Direito Civil. 


\section{Summary}

1. Non-discrimination as a "general principle of EU law" - "spill-over" effects on private law?

2. Non-discrimination in employment law relations

3. EU Citizenship - extending the scope of the principle of non-discrimination by primary law

4. Extension of the non-discrimination principle to business-consumer (B2C) relations by EU secondary law

5. A recent controversy: Unisex tariffs in insurance and conflicts with private autonomy

6. Non-discrimination of access to and treatment in services of general economic interest and in network services: limited autonomy

7. Effective remedies and sanctions in cases of discrimination

8. Conclusion: From an "individualistic" concept of discrimination to an understanding of its collective dimension

References 


\section{Non-discrimination as a "general principle of EU law" - "spill-over" effects on private law?}

The concept of non-discrimination, also called "equal treatment", plays an important role in Union law, and many cases decided by the Court of Justice of the EU understand it as a general constitutional principle ${ }^{1}$. With regard to the economic law of the Union, market subjects should be treated as equals if they are in a comparable situation, or inversely, law should not impose equal treatment on them if they are in different situations, unless such differentiation is objectively justified ${ }^{2}$. The Codorniu case provides us with an example. ${ }^{3}$ The Court invalidated a Community regulation forbidding Spanish producers from using the traditional term crémant by reserving it to French and Luxembourg producers of sparkling wine. The measure was held to violate the principle of non-discrimination because Spanish producers were put on an unequal basis relative to other producers without justification.

Over time EU non-discrimination law, apart from the distinctly marketorientated approach, has taken on also a social dimension by including within its ambit the struggle against discrimination based on gender, race, ethnic origin, age, disability or sexual orientation. This development is part of a more general trend concerned with fundamental rights in the EU. Article 21 on "Non-discrimination" of the Charter of Fundamental Rights, which became formally part of EU law after the Lisbon Treaty was ratified, but which had guided the Court of Justice in its interpretation and application of Community law beforehand ${ }^{4}$, reads:

1. Any discrimination based on any ground such as sex, race, colour, ethnic or social origin, genetic features, language, religion or belief, political or any other opinion, membership of a national minority, property, birth, disability, age or sexual orientation shall be prohibited.

1 This is the understanding of the ECJ case law on the importance of general principles in EU law enjoying a "constitutional status" by see LENAERTS, K/ GUTIÈRREZ-FONS,J., The Constitutional Allocation of Powers and General Principles of EU Law, CMLRev 2010, 1629 at p. 1647 ; for an overview see also TRIDIMAS, T., The General Principles of EU Law, $2^{\text {nd }}$ ed.2006, at 59-64; REICH et al. , Understanding EU Internal Market Law, $3^{\text {rd }}$ ed. 2012 at $\$ 12.2$; BASEDOW, J. Grundsatz der Nichtdiskriminierung, Zeitschrift für Europäisches Privatrecht (ZEuP) 2008, 230 at 232; MAZIÈRE, P., Le principe d'égalité en droit privé, 2003, p. 429.

2 Cases 117/76 + 16/77 Ruckedeschel [1977] ECR 1753 \& 7; C-15/95, EARL de Kerlast v Union régionale de coopératives agricoles (Unicopa) and Coopérative du Trieux [1997] ECR I-1961 at \35; C-127/07 Arcelor Atlantique and Lorraine and Others [2008] ECR I-9835, \ 23.

Case C-309/89 Codorniú Sa v Council [1994] ECR I-1853.

For the general approach of the ECJ in applying the Charter even before its formal enactment see case C-540/03 EP v Council [2006] ECR I-5769; for a specific example see case C-272/06 Productores de Música de Espana (Promusicae) v Telefónica de Espana SAU [2008] ECR I-271 SS 62-63 on the need to balance between the right to effective protection of property (copyright) and the right of protection of personal data and hence of private life in civil litigation between a rights management society and internet providers concerning disclosure of user data of copyrighted music. 
2. Within the scope of application of the Treaty... and without prejudice to the special provisions ... any discrimination on grounds of nationality shall be prohibited.

Article 23 of the Charter contains a specific provision on "Equality between men and women", including but not limited to employment relations:

Equality between men and women must be ensured in all areas, including employment, work and pay. The principle of equality shall not prevent the maintenance or adoption of measures providing for specific advantages in favour of the under-represented sex.

Those are obviously broad formulations which need to be transformed into legal "rights" by EU-legislation and court practice. They are addressed to the Union itself and, according to the general clause of Article 51 of the Charter, to the Member States "only when they are implementing Union law", which must be read as meaning "acting within the scope of EU law". The more extensive understanding of the Charter's scope of application corresponds to the existing case law of the Court of Justice on the application of general principles of fundamental rights. ${ }^{5}$ What can be seen both in the pre-existing case law of the Court of Justice on the principle of non-discrimination, as well as its Charter manifestation, the rights it gives rise to have a "vertical direction" - in relation to the Union or the Member States, the latter including any body or institution governed by public law.

In this chapter I would like to discuss another dimension of the principle of non-discrimination in EU law. I will focus my analysis on private law relations which in all Member States ${ }^{6}$ and in Union law ${ }^{7}$ itself are subjected to the principle of private autonomy. The significance of the principle of private autonomy has recently been confirmed in Article 1 of Annex I of the Commission Proposal of a "Common European Contract Law" (CESL) of 11 October 2011". However, an inevitable clash exists between the rationale behind the principle of non-

5 See case 5/88 Wachauf v Bundesamt für Ernährung [1989] I-2609 S 19 and now case C-279/09 DEB Deutsche Energiehandels- und Beratungsgesellschaft mbH v Bundesrepublik Deutschland, [2010] ECR I-(22.12.2010); LENAERTS, K/ GUTIÈRREZ-FONS,J., The Constitutional Allocation of Powers and General Principles of EU Law, CMLRev 2010, 1629., supra note 1 at p. 1660; a more restrictive opinion has been taken by Borowsky, in:MEYER, J., Kommentar zur Charta, $3^{\text {rd }}$ e-book ed. 2011, Article 51, \14; a narrower reading ahs been suggested by CREMER, W., Grundrechtsverpflichtete und Grundrechtsdimensionen nach der Charta der Grundrechte in der EU, EuGRZ 2011, 545, strictly distinguishing between "Durchführung" (implementation) and "Anwendungsbereich" (scope of application) of Union law by Member States.

6 See the overview of the development of "contract law under aspects of social justice" in England, France and Germany by MICKLITZ (ed.), The Many Concepts of Social Justice in European Private Law, 2011, pp. 8

7 Case C-277/05 Sociéte thermale d'Eugénie-les-Bains v Ministère de l'Economie, des Finances et de Industrie, [2007] ECR I-6415 28: „,..parties are at liberty - subject to the mandatory rules of pulic policy- to define the terms of their relationship...“

8 COM (2011) 635. 
discrimination and the logic of private law fuelled by the concern for economic efficiency. Private law allows "discrimination" - or rather differentiation - of parties, in particular on grounds of economic efficiency. This entitlement to differentiate is protected by the fundamentals of private law relations, namely freedom of contract and party autonomy, which the application of the principle of non-discrimination would contradict. This explains why in the context of company law, the Court of Justice, drawing on a thorough opinion of AG Trstenjak, rejected the existence of an equality principle of "constitutional status". In doing so the Court agreed with the prevalent academic opinion, expressed for example, in an article authored by a prominent German scholar, Jürgen Basedow ${ }^{10}$ :

\begin{abstract}
"The principles of equality or the prohibition of discrimination are not part of the traditional principles of private law. He who concludes a contract does this in his own interest and not in order to do justice to others. She who has to choose a contract partner among several candidates has according to a German saying the "pain of choice" because there usually exist several selection criteria, the relative value of which can only be assessed with reference to subjective preferences..." (translation NR).
\end{abstract}

In his article Basedow undertakes a detailed and critical analysis of primary and secondary EU law, as well as of the practice of the Court of Justice, and comes to the conclusion that "there are only limited and selective prohibitions of discrimination, usually aimed at creating balance in situations of power, and not a general prohibition of discrimination in the conclusion of contracts." ${ }^{\prime 1}$

The purpose of this chapter is challenge the traditional conception of private law whereby non-discrimination is not one of its constituting principles. Drawing on an argument which I presented elsewhere ${ }^{12}$ I will show that the traditional distinction between public and private law which is so dear to continental lawyers does not exist in EU law. For this reason, it cannot be used to "shield" private law against provisions and concepts of non-discrimination. This does not imply that party autonomy should not be recognised as one of the "fundamental pillars" of EU law. ${ }^{13}$ It is finding its place in the "Freedom to conduct a business" under

9 C-101/08 Audiolux [2009] ECR I-9823 § 63; BASEDOW, J. Grundsatz der Nichtdiskriminierung, Zeitschrift für Europäisches Privatrecht (ZEuP) 2008, at 232 J. Basedow, Mangold, Audiolux und die allgemeinen Grundsätze des europäischen Privatrechts, in: FS Klaus Hopt, 2010, 27 ff. For a broader discussion see the paper by HESSELINK, M., The general principles of civil law: Their nature, role and legitimacy, this volume at pp.**

10 BASEDOW, J. Grundsatz der Nichtdiskriminierung, Zeitschrift für Europäisches Privatrecht (ZEuP) 2008, 230 at 232 at p. 230.

11 At 250.

12 For details see Reich, The public/private divide in European law, in: CAFAGGI/MICKLITZ (ed.), After the Common Frame of Reference, 2010, 56.

13 For a discussion see HESSELINK, If You Don't Like Our Principles We Have Others, in: Brownsword et al. (eds.), The Foundations of European Private Law, 2011, pp. 59 with critical reference to the so-called underlying principles" to the Outline Edition of the DCFR of 2009. 
Article 16 and the "Right to property" under Article 17 of the Charter. My view is, however, that private autonomy should balanced against other "constitutional principles", such as the protection of the weaker party and the ordre public of the European Union, as recognised by Article 52(1). ${ }^{14}$

It will be shown in this chapter that this balancing between the seemingly conflicting principles of autonomy and non-discrimination is relative with respect to two factors. First, the location of balance will depend on the area of law in the context of which the non-discrimination principle is invoked. There will be different rules in employment law, consumer law, services in the general public interest on the one hand, and in genuine commercial relations which are only subject to the competition rules on the other. Secondly, only certain characteristics on the basis of which discrimination occurs can be taken into account in EU law (the "legally incriminated grounds of discrimination"15). The EU prohibition of discrimination is typically based on such personal characteristics as gender, ethnic origin, nationality, age, sexual orientation which are part of the identity of a person (askriptive Perönlichkeitsmerkmale), as explained by Schiek, ${ }^{16}$ but not so much on economic grounds like income, social or family status and similar characteristics. The questions of 'equal treatment' implies a value judgment on a 'limited list of characteristics that are considered to be so delicate as to lead to every differentiation which is made on the basis of such characteristic to be considered discriminatory" ${ }^{\prime \prime}$. Articles 21 and 23 Charter contain such (long) lists of 'incriminated' characteristics.

The following sections will discuss the non-discrimination law in the EU with regard to both the area concerned and the characteristic applied. It will be shown that a differentiated answer is necessary to adequately understand the impact of the non-discrimination principle on private law in the Union.

\section{Non-discrimination in employment law relations}

The first context in which the principle of non-discrimination was pronounced in EU law was that of employment. The principle of equal treatment between men and women with regard to pay for work of the same value had been part of the original EEC Treaty. The well known Defrenne II-judgment ${ }^{18}$ insisted on the horizontal direct effect of the principle of equal pay in what was then Article 119

14 REICH, Balancing in Private Law and the Imperatives of the Public Interest, in Brownsword et al, pp. 221.

15 COUSY, H., Discrimination in Insurance Laws, in: R. Schulze (ed.), Non-Discrimination in European Private Law, 2011, 81 at 83.

16 For a broader discussion see SCHIEK, D., Differenzierte Gerechtigkeit, 2000, pp. 27 ff.

17 COUSY, H., Discrimination in Insurance Laws, in: R. Schulze (ed.), Non-Discrimination in European Private Law, 2011 p. 84.

18 Case 43/75 G. Defrenne v SABENA, [1976] ECR 455; for details see Reich supra note * at pp. 59. 
EEC (now Article 157 TFEU). Equal access to employment and equality in working conditions were not part of primary Community law, as was firmly established by the Court in its Defrenne III-judgment ${ }^{19}$, and therefore had to be introduced by secondary law, namely Directive $76 / 207^{20}$ - a directive which through extensive case law of the Court of Justice has acquired a constitutional status ${ }^{21}$. The Directive has also given rise to a long-standing debate about its horizontal effect, a theme to which I will refer later (7.).

A bold new "constitutional approach" was taken by the Court of Justice in the context of age discrimination in employment law in the Mangold litigation". The main question in that case was whether Germany, though not yet formally bound by the Framework Directive 2000/78/EC 23 prohibiting under certain circumstances any discrimination based on age, violated a general principle of discrimination in lowering the age limit for fixed term contacts. In his opinion of 30 June 2005, AG Tizzano wrote:

\begin{abstract}
"It may also be recalled that, even before the adoption of Directive $2000 / 78$ and the specific provisions it contains, the Court had recognised the existence of a general principle of equality which is binding on Member States 'when they implement Community rules' and which can therefore be used by the Court to review national rules which 'fall within the scope of Community law'. That principle requires that 'comparable situations must not be treated differently and different situations must not be treated in the same way unless such treatment is objectively justified by the pursuit of a legitimate aim and provided that it 'is appropriate and necessary in order to achieve' that aim" (\82).
\end{abstract}

The Court largely adopted this argument, thereby de facto eliminating the special "délai de grace" afforded to Germany for implementation:

\begin{abstract}
"The principle of non-discrimination on grounds of age must thus be regarded as a general principle of Community law. Where national rules fall within the scope of Community law, .... and reference is made to the Court for a preliminary ruling, the Court must provide all the criteria of interpretation needed by the national court to determine whether those rules are compatible with such a principle... " (\$ 75$)$.
\end{abstract}

Council Directive 76/207/EEC treatment for men and women as regards access to employment, vocational training and promotion, and working conditions [1976] OJ L039/40.

21 The ECJ had recognised the extension of the general principle of non-discrimination as a fundamental right of the then Community with regard to sex in its seminal case C-25/02 Katharina Rinke v. Ärztekammer Hamburg, [2003] ECR I-8349.

22 Case C-144/04 Werner Mangold v Rüdiger Helm, [2005] ECR I-9981.

23 Council Directive 2000/78/EC of 27 November 2000 establishing a general framework for equal treatment in employment and occupation [2000] OJ L 303/16. 
This proclamation of a general principle of non-discrimination on grounds of age has given rise to an intense and mostly critical discussion amongst legal scholars $^{24}$. It was also criticised in a subsequent opinion of AG Mazak in Palacios de la Villa $^{25}$, which noted that the international instruments and constitutional traditions referred to in Mangold did enshrine the general principle of equal treatment, but it had been a bold proposition and a significant step to infer from that the existence of a specific principle prohibiting age discrimination. The AG also referred to the Grant case $^{26}$, in which the Court of Justice held that Community law, as it stood, did not cover discrimination based on sexual orientation. The Court remained unimpressed by the criticism which its judgment in Mangold received. In Kücükedevici ${ }^{27}$ it repeated its broad approach to the non-discrimination principle (in respect to age in employment relations).

To the surprise of many observers, who read the Lisbon judgment of the Bundesverfassungsgericht (the German Constitutional Court) of 30 June 2009, and the earlier Maastricht judgment of the same court of 12 October1993) ${ }^{28}$ as a challenge to the supremacy doctrine of the Court of Justice of the EU, the socalled Honeywell-order of 6 July $2010^{29}$ basically endorsed the Mangold case law. Strict limits were put on the ultra-vires control of judgments of the Court of Justice of the EU under German constitutional law. The Bundesverfassungsgericht held that it would use its powers only in cases of a "sufficiently serious" (hinreichend qualifiziert) violation of competences:

This requires that the action of a Union authority be regarded as manifest and that the attacked act leads to a structurally important modification of competences to the detriment of Member states in the EU."

24 For an overall discussion see METZGER, A. Extra legem, intra ius: Allgemeine Rechtsgrundsätze im Europäischen Privatrecht, 2009, at pp. 344-346; critique REICH, Europäische Zeitschrift für Wirtschaftsrecht (EuZW) 2006, 21; 2007, 198; BASEDOW, J. Grundsatz der Nichtdiskriminierung, Zeitschrift für Europäisches Privatrecht (ZEuP) 2008, BASEDOW, J. The Court of Justice and Private Law, ERevPrL 2010, 443 at pp. 463; SPAVENTA, E., The Horizontal Application of Fundamental Rights as General Principles of Union Law, in: ARNULL et al. (eds.), A Constitutional Order of States Essays in Honour of A. Dashwood, 2011, pp. 199 ff.; an interesting methodological argument combining primary EU law, general principles and secondary law has been advanced by DOUGAN, M., In Defence of Mangold?, in: Arnull et al., A Constitutional Order of States - Essays in Honour of A. Dashwood, pp. 219 ff.;further references in the opinion of AG Sharpston in case C-427/06 [2008] B. Bartsch v. Bosch and Siemens (BSH) Altersfürsorge] ECR I-7245 which concerned the compatibility of a so-called "age-gap" clause in a pension scheme with primary (Article 13 EC) or secondary (Directive 2000/78) Community law.

25 Case C-411/05, Palacios de la Villa [2007] ECR I-8531.

26 Case C-249/96 Lisa Jacqueline Grant v South-West trains [1998] ECR I-621; the EU-legislator reacted by Directive 2000/78; it is however not clear whether Grant would be decided differently.

27 Case C-555/07 Seda Kücükdevici Swedex GmbH [2010] ECR I-365, recently confirmed by case C-447/09, R. Prigge et al v Lufthansa, [2011] ECR I-(13.9.2011) \& 38; ; the broad approach of the Court has been criticised by Dougan, supra note 24, at pp.238 f. .

28 BVerfGE 89, 155 (English translation [1994] 1CMLR 57; 123, 267 ([2010] 3 CMLR 13).

29 BverfGE 126, 286 with dissenting opinion by Judge Landau referring to the Lisbon judgment and criticising the Mangold-judgment of the ECJ, pp. 318, 324. 
In Honeywell the Bundesverfassungsgericht expressly recognised the power of the Court of Justice of the EU to create law (Rechtsfortbildung) by “....methodologically constrained case law (methodisch gebundene Rechtsprechung) basing on primary and secondary law as well as on unwritten general principles of the constitutional traditions of the Member states...". It also put strict procedural restrictions on any ultra vires control; only the Bundesverfassungsgericht was held to have the power to declare Union acts non-applicable in Germany, and the Court of Justice of the EU was recognised the privilege of having a possibility to clarify its position before such the decision of non-applicability is taken. This meant that in order for the plea for setting aside the Union act (including the judgment of the CJEU) could be successful a German court, other than the Bundesverfassungsgericht, had first to make a reference to the Court of Justice. The practical result of this ruling was a recognition by the German Constitutional Court of the precedence of CJEU judgments insofar as they concern interpretation of EU law and fall within the Court's mandate under Article 19 (1) TEU to "ensure that .... the (italics NR) law is observed", which includes the further development and application of general constitutional principles, such as the principle of non-discrimination. ${ }^{30}$

Following the Honeywell ruling, the Bundesarbeitsgericht (the Federal Labour Court) in the judgment of 9 September 2010 disapplied the contested German provision $(\$ 622(2) \$ 2$ BGB) which discriminated against young employees with regard to the notice period for termination of employment by excluding from calculation the employment period accrued before the age of $25 .{ }^{31}$ In its stead the court simply used the general rule contained in $₫ 622(2) \$ 1$ on the calculation of the length of employment.

A debate similar to Mangold followed also another case decided by Court of Justice of the EU. Römer ${ }^{32}$ concerned an alleged discrimination of registered samesex couples, in comparison to regularly married persons, in the (German) system of supplementary retirement pensions for former employees of local authorities. In a strong but controversial opinion of 15 July 2010, AG Jääskinen, referring to Mangold and Kücükdevidci, found acts of discrimination with regard to tax and related benefits to have been committed already from 2001 onwards, the time of the registration of the partnership, and not from 2003, where the Member States were to implement Directive 2000/78/EC. This finding was supported by the view that the principle of non-discrimination on grounds of sexual orientation was in operation even before the transposition deadline for the Directive had expired. Its

30 For a discussion on the importance of the, Honeywell “- order of the BVerfG see PAYANDH, CMLRev 2011,9.

31 BAG, 2 AZR 714/08, Zeitschrift für Wirtschaftsrecht (ZIP) 2011, 444.

32 Case C-147/08 Jürgen Römer v Freie und Hansestadt Hamburg [2010] ECR I-(10.5.2011); critique of the opinion of AG Jääskinen: Reich, EuZW 2010, 685. 
status of a 'general principle' was evidenced by Article 21 of the Charter and the ECHR law. In its judgment of 10 May 2011, the Court of Justice decided not to follow its Mangold-type approach to discrimination. It followed the AG only insofar as he condemned the discrimination of registered same-sex couples concerning their exclusion from the pension scheme. However, Germany was not held to have been bound by the principle of non-discrimination on grounds of sexual orientation before the date of implementation of the Directive. Discrimination suffered by the couple after their partnership was registered but before the Directive's transposition deadline remained outside the scope of EU law. The Court of Justice thereby, without expressly distinguishing Mangold, implicitly denied the existence in EU law of a general principle of non-discrimination of same-sex partners predating the coming into effect of the Charter of Fundamental Rights.

The ACCEPT-case ${ }^{33}$ concerned a discrimination on grounds of sexual orientation by a leading figure of the Roumanian football club FC Steaua, Mr. Becali on the transfer of a professional football player of alleged homosexual orientation. $\mathrm{Mr}$ Becali in strong words to the public had stated:

"Not even if I had to close [FC Steaua] down would I accept a
homosexual on the team. Maybe he's not a homosexual. But what if
he is? There's no room for gays in my family, and [FC Steaua] is my
family. Rather than having a homosexual on the side it would be better
to have a junior player. This isn't discrimination: no one can force me
to work with anyone. I have rights just as they do and I have the right
to work with whoever I choose. Even if God told me in a dream that
it was 100 percent certain that X wasn't a homosexual I still wouldn't
take him. Too much has been written in the papers about his being a
homosexual. Even if [player X's current club] gave him to me for free
I wouldn't have him! He could be the biggest troublemaker, the biggest
drinker ... but if he's a homosexual I don't want to know about him."

The question before the ECJ did not so much turn about the discriminatory aspects of the statement of Mr. Becali but most of all on whether this could be attributed to the Club of which he owned shares but did not have any formal position of management. The Court answered as follows, referring to its earlier AGM-COSMET judgment: ${ }^{34}$

"It follows that a defendant employer cannot deny the existence of facts from which it may be inferred that it has a discriminatory recruitment policy merely by asserting that statements suggestive of the existence of a homophobic recruitment policy come from a person who, while claiming and appearing to play an important role in the management of that employer, is not legally capable of binding it

33 Case C-81/12 Asociatia ACCEPT v CNPCD [2013] ECR I-(25 April 2013)
34 Case C-470/03 AGM-COSMET [2007] ECR I-2749 SS 55-58. 
in recruitment matters. In a situation such as that at the origin of the dispute in the main proceedings, the fact that such an employer might not have clearly distanced itself from the statements concerned is a factor which the court hearing the case may take into account in the context of an overall appraisal of the facts" $\left.\iint 49-50\right)$.

As a result of this argument, the club cannot hide itself behind the formal allocation of competences and has an obligation to distance itself from homophobic statement made in its name.

\section{EU Citizenship - extending the scope of the principle of non- discrimination by primary law}

Primary EU law has extended the principle of non-discrimination to private law situations, under specific circumstances, beyond employment. An example of this trend is the use of the concept of citizenship of Article 17 EC (now Article 20 TFEU) to expand the scope of the prohibition of discrimination based on nationality, which applies only "within the scope of application of the Treaty" (Article 18 TFEU, ex Article 12 EC). The application of the non-discrimination principle is seen as a step to guarantee the autonomy of persons as EU citizens to enjoy a bundle of rights, in particular the right to free movement in a broader sense. In the exercise of their free movement rights EU citizens should not be unduly restricted by relations normally coming under the regime of private law.

Although there has yet been no case concerning discrimination in private law relations, the arguments developed by the Court of Justice with regard to fundamental freedoms, namely the existence of a "collective regulation" (or an employment contract in the sense used by the Court in Raccanelli) ${ }^{35}$, can also be used to attack nationality clauses in standard contract forms, or in by-laws of private associations like boarding schools or private universities concerning admission, tuition or employment.

This "constitutional approach" to non-discrimination which perceives equality as a necessary attribute of the position of individuals as EU citizens has also been used by the Court in cases involving challenges to national legislation on surnames, usually a matter of (non-harmonised) private international law. In Garcia Avello $^{36}$ the Court had to decide whether the Belgian law on names of children, which, unlike Spanish law, excluded the use of both parents' surnames, could be

36 Case C-148/02, [2003] ECR I-11613; for its importance on fundamental rights protection of economically inactive citizens see ELSMORE, M. \& STARUP. P., Union Citizenship - Background, Jurisprudence, and Perspective, YEL 2007, 57 at 92. 
applied to children of Belgian citizens who also held Spanish citizenship. The Court relied on the "second limb" of the non-discrimination principle, namely that "... different situations should not be treated alike, unless this is objectively justified" to rule that:

\begin{abstract}
"In contrast to persons having only Belgian nationality, Belgian nationals who also hold Spanish nationality have different surnames under the two legal systems concerned. More specifically, in a situation such as that in issue in the main proceedings, the children concerned are refused the right to bear the surname which results from application of the legislation of the Member State which determined the surname of their father" (\$ 35$)$.
\end{abstract}

The Court did not find any justification for applying the strict Belgian law on names to the Avello children to the effect that they were unable to use their doublebarrelled surnames. In a later case, Grunkin and Paul, ${ }^{37}$ the Court of Justice adopted different reasoning from that in Garcia Avello, although the case also concerned the autonomy in the choice of the surname format. The Grunkin and Paul case was brought by a German citizen born in Denmark, where his name was determined according to the ius soli, which allowed him to take the last name of both of his father and mother, while under the German ius sanguinis and lex nationalitis his parents were forced to choose between the last name of the father or that of the mother. When he settled in Germany he applied to maintain his Danish doublebarrelled name, but the request was refused the competent German authority. In its judgment of 13 October 2008 the Court regarded German legislation on names as an unjustified, non-proportional interference with the free movement rights of a Union citizen, rather than with the principle of non-discrimination principle, as it was the case in Garcia Avello.

Interestingly, in both Garcia Avello and Grunking and Paul the litigation concerned a "vertical" conflict between an EU citizen and a Member State, namely a national agency or a court that determined the question of name. However, the substance of the cases concerns a private law question, that of a name of a citizen, which in trans-border situations is determined by the rules of private international $\operatorname{law}^{38}$. This particular aspect of private international law is not harmonised by primary or secondary EU law. Yet, Member States are still asked to avoid discrimination of citizens of other Member States, as in Garcia Avello, or refrain from creating unjustified restrictions on free movement, as in Grunkin and Paul.

37 Case C-353/06 Grunkin and Paul [2008] ECR I-7639; see already the opinion of AG Jacobs of 30.6.2005 in the preceding case C-96/04 [2006] I-3561 where the ECJ however regarded the reference as inadmissible. In his earlier opinion of 9.12.1992 in case C-168/01 Konstantinidis [1993] ECR I-1191, argued before the enactment of the citizenship concept in EU law, AG Jacobs pointed to the fundamental right of a person to his name as part of European citizenship: "civis Europeus sum" at $\$ 46$; the Court argued with the somewhat artificial market aspects of distorting the spelling of a name which may create confusion with potential clients of Mr. Konstantinidis and therefore restrict non proportionally his right to establishment.

38 LAGARDE, P., Droit international privé, in:SCHULZE/SCHULZE/-NÖLKE (eds.), European Private Law - Current Status and Perspectives, 2011, 249 at pp. 257. 


\section{Extension of the non-discrimination principle to business-consumer (B2C) relations by EU secondary law}

Secondary law has extended the discrimination prohibitions onto private law relationships beyond employment ${ }^{39}$ with reference to grounds such as ethnic and racial origin (Article 3(1)(h) of Directive 2000/43/EC ${ }^{40}$ ), sex (Article 5(1) of Directive2004/113/EC ${ }^{41}$ ), and legal residence (Article 11(1)(f) of the Longterm Resident Directive 2003/109/EC ${ }^{42}$ ). The situation in which individuals are protected by EU law cover the "access to and supply of goods and services available to the public". "Housing" is mentioned only in Directive 2000/43, not in Directive 2004/113; Directive 2003/109 is limited to "procedures for obtaining housing". Therefore, not every differentiation in the selection of contract partners is a violation of EU law; there must already be an initial availability of certain goods and services to the public, for example via advertising or marketing ${ }^{43}$. Article 3(2) of Directive 2004/113 and its recital 14 expressly guarantee the freedom to choose a contractual partner, so long as it is not based on the person's sex. Special rules apply to insurance contracts (see below section 5). Both intentional and indirect discrimination is prohibited, the latter situation being where seemingly neutral provisions create unjustified negative effects ${ }^{44}$.

On 2 July 2008 the Commission proposed to extend the principle of equal treatment between persons irrespective of religion or belief, disability, age or sexual orientation also to private law relations outside the labour market, in particular to

39 For an overview see SCHIEK,D et al. (eds.), Non-discrimination law, 2007, 11-14; REICH et al. , Understanding EU Internal Market Law, $3^{\text {rd }}$ ed. 2012 at $\int 12.19$. BASEDOW, J. Grundsatz der Nichtdiskriminierung, Zeitschrift für Europäisches Privatrecht (ZEuP) 2008 at 238 differentiates between a genuine „prohibition of discrimination“, which is not the formulation of the directives, and the need to „combat discrimination“, eg according to Article 1 Directive 2000/43; its Article 2 (1) formulates that „there shall be no direct or indirect discrimination based on race or ethnic origin. “ Is the latter formula really a difference to a „prohibition“ strictu sensu? Otherwise the need for effective sanctions would not be understandable. Obviously, the Member states have a certain amount of discretion on how to implement this obligation.

40 [2000] OJ L 180/22.

41 [2004] OJ L 373/37.

42 [2004] OJ L 16/44.

43 REICH et al., Understanding EU Internal Market Law, $3^{\text {rd }}$ ed. 2012 at $\int 12.29$; SCHEREIER, M. Das Allgemeine Gleichbehandlungsgesetz - wirklich ein Eingriff in die Vertragsfreiheit? KRITJ 2007, 278 at 285 referring to the somewhat misleading term in the implementing German legislation (AGG - Allgemeines Gleichbehandlungsgesetz von 2006),, Massengeschäft “ in contrast to, individual transactions" where personal characteristics of the partner are important.; analysis by RIESENHUBER, K., Das Verbot der Diskriminierung aufgrund der Rasse und der ethnischen Herkunft sowie aufgrund des Geschlechts beim Zugang zu und der Versorgung mit Gütern und Dienstleistungen, in: Leible/S chlachter, Diskriminierungsschutz durch Privatrecht, 2007, pp. 124 at p. 129 insisting on ,objective criteria“.

44 RIESENHUBER, K., Das Verbot der Diskriminierung aufgrund der Rasse und der ethnischen Herkunft sowie aufgrund des Geschlechts beim Zugang zu und der Versorgung mit Gütern und Dienstleistungen, in: Leible/S chlachter, Diskriminierungsschutz durch Privatrecht, 2007, at p. 133; COUSY, Discrimination in Insurance Law, in: SCHULZE (ed.), Non-discrimination in European Private Law, 2011, 81 at p. 85 
consumer markets where "access to and supply of goods and services available to the public, including housing" are concerned. The proposal has been met with a strong resistance from the Member States. ${ }^{45}$ While allowing some exceptions, the German Allgemeine Gleichbehandlungsgesetz. (AGG) of 14 August 2006 already contains a similar provision in its $₫ 19$.

\section{A recent controversy: Unisex tariffs in insurance and conflicts with private autonomy}

a. A "monist" reading of the non-discrimination principle by the ECJ?

A more recent debate concerns the problem of whether the EU legislator may restrict the non-discrimination principle in a directive aimed at combating discrimination. This question arose in an action brought by the Belgian consumer association Test Achats before its Constitutional Court, which then referred the matter to the Court of Justice, the sole competent judicial authority to invalidate EU acts $^{46}$. The Belgian Constitutional Court's question concerned the validity of Article 5(2) of the above mentioned non-discrimination directive (Directive 2004/113/ EC), which reads:

\footnotetext{
"Notwithstanding paragraph 1, Member States may decide before 21 December 2007 to permit proportionate differences in individuals' premiums and benefits where the use of sex is a determining factor in the assessment of risk based on relevant and accurate actuarial and statistical data. The Member States concerned shall inform the Commission and ensure that accurate data relevant to the use of sex as a determining actuarial factor are compiled, published and regularly updated. These Member States shall review their decision five years after 21 December 2007, taking into account the Commission report referred to in Article 16, and shall forward the results of this review to the Commission."
}

Could this exception relating to an autonomous (even though somewhat camouflaged by reference to statistics) rate of insurers' calculation be upheld against the general principle of non-discrimination with regard to sex which is enshrined in Article 21(1) and 23 of the EU-Charter of Fundamental Rights, which has become binding from 1 December 2009 on all EU institutions? The opinion of AG Kokott of 30 September $2010^{47}$ in very strong words condemns this exception

45 COM (2008) 426 final; for a disucssion see VANDENBERGHE, A.-S., Proposal for a new Directive on non-discrimination, ZEuP 2011, 235.

46 Case C-236/09 Ass. Belge Test Achats et al. [2011] ECR I-773; see the detailed comments on the Belgian legislation by COUSY, H. COUSY, Discrimination in Insurance Law, in: SCHULZE (ed.), Nondiscrimination in European Private Law, 2011 at pp.99.

47 Critique KARPENSTEIN, U., Harmonie durch die Hintertür? Geschlechtsspezifisch kalkulierte Versicherungstarife und das Diskriminierungsverbot, EuZW 2010, 885. 
in secondary law as violating the higher ranking EU non-discrimination principle itself. She writes:

\begin{abstract}
"(W)ith Directive 2004/113, particularly with Article 5, the Council made a conscious decision to adopt anti-discrimination legislation in the field of insurance. Such provisions must, without restriction, withstand examination against the yardstick of higher-ranking European Union law, in particular against the yardstick of the fundamental rights recognised by the Union. They must, to use the words of Article 13(1) EC (now Article 19(1) TFEU), be 'appropriate' for combating discrimination; they may not themselves lead to discrimination. The Council cannot evade that examination by simply arguing that it could also have taken no action" ( $(35)$.
\end{abstract}

She has also rejected the argument that gender is one of the actuarial factors which could be taken into account for risk-assessment in life, health, and caraccident insurance:

\begin{abstract}
"In view of social change and the accompanying loss of meaning of traditional role models, the effects of behavioural factors on a person's health and life expectancy can no longer clearly be linked with his sex. To refer once again to a few of the examples just mentioned: both women and men nowadays engage in demanding and sometimes extremely stressful professional activities, members of both sexes consume a not inconsiderable amount of stimulants and even the kind and extent of sporting activities practised by people cannot from the outset be linked to one or other of the sexes“ ( $($ 63).
\end{abstract}

On 1 March 2011 the Court of Justice condemned the exemption from the non-discrimination principle in insurance contracts by ruling:

"Article 5(2) of Council Directive 2004/113/EC of 13 December 2004 implementing the principle of equal treatment between men and women in the access to and supply of goods and services is invalid with effect from 21 December 2012."

The judgment is surprisingly short ${ }^{48}$, quite in contrast to the lengthy opinion of AG Kokott. The Court of Justice shows willingness strictly to control the conformity of EU provisions with the human rights regime to which the EU subscribed in a number of documents, the latest one being the "elevated" Charter of Fundament Rights, which from 1 December 2009 has the same value as the EU Treaties. The Court's ruling is based on several arguments. First, the Charter is not directly used to assess conformity of Article 5(2) of Directive 2004/113 because the Charter was not yet a binding document at the time when the non-discrimination

48 Comment REICH, N., Some Thoughts after the,,Test Achats“Judgment, EJRR 2011, 283; PURNHAGEN, K., EuR 2011, 690; D. Effer-Uhe, Gleichbehandlung in Versicherungsverträgen, in: SCHULZE (ed.), Non-discrimination in European Private Law, 2011, 42, pp. 109 ff; Chr. TOBLER, CMLRev 2011, 2041. 
directive was adopted (13 December 2004), or became binding upon the Member States (21 December 2007). Instead, the Charter had relevance only by an "autoreference" of the Directive to Article 21 and 23 of the Charter as a document expressing the political will of the Union (than the Community) to protect and promote fundamental rights, including the equality of sexes. ${ }^{49}$ The Court also refers to the fact that "the right to equal treatment for men and women is the subject of (several) provisions of the FEU Treaty" ${ }^{\prime \prime}$.

Secondly, the Court recognises that such equality cannot be simply produced by "legal fiat", but contains an evolutionary element which must be "progressively achieved" 51 . The EU non-discrimination directives do not immediately forbid discrimination but contain a (mandatory!) political programme to be elaborated and implemented over time. The Union itself via legislation and the Member States, as well as the private actors (insurance companies doing business in the EU according to the relevant legislation), to which the equality regime is addressed in the end, must cooperate in this task, for example, by offering "unisex" tariffs from a date to be determined by legislation. In order to fulfil this dynamic element of nondiscrimination, legislative action "...must contribute, in a coherent manner (emphasis NR), to the achievement of the intended objective, without prejudice of providing for transitional periods or derogations of limited scope" 52 . This "inner-legislative" coherence requires that such periods be limited in time. They cannot last "eternally" or give Member States or companies unfettered discretion on how to achieve this objective. Since such a limited period was missing from the directive, the Court invalidated it, but only with ex nunc consequences, beginning after five years of the Directive's entry into force. This is a courageous step, but well known of the case law of the German Constitutional Court, which frequently invalidates a legislative measure held to violate fundamental rights only with ex nunc effect, in order to give the legislator time to remedy the complex political, economic or legal situations.

The Court of Justice expressly condemned the exemption in Article 5(2) as a violation of the equality principle, which was (and still is) the basis for legislative action under Article 13 EC (now Article 19 TFEU). Under a consistent case law, the Court of Justice defines the principle of equal treatment as requiring that "comparable situations must not be treated differently, and that different situations must not be treated in the same way, unless such treatment is objectively justified" ${ }^{53}$. Despite the different risk profiles of sexes in certain types of insurance, like the third party liability of car drivers, where men seem to take more risks and are responsible for more accidents, on the one hand, and life and health insurance,

49 \ 17 of the judgment See KOSTA, V. , Internal Market Legislation and the Private Law of the Member States - The Impact of Fundamental Rights, ERCL 2010, 409.

$50 \int 18$.

$51 \int 20$.

$52 \int 21$.

$53 \int 28$. 
where women have a higher and more costly risk profile according to relevant statistics, these differences were expressly ruled out as relevant by Article 5(1) of Directive 2004/113. Men and women, despite the difference in life expectancy, have to be treated as "normatively comparable" even though "empirically different" ${ }^{54}$. The Court of Justice did not find any justification for this differentiation to continue without a time limit. It amounted to a discrimination "pure and simple" to persist indefinitely ${ }^{55}$. In order to remedy this situation, the Court took upon the position of legislator and imposed a time limit on its own accord, without invalidating the entire legislative act. As a consequence, existing insurance contracts with different premiums, tariffs and benefits for men and women, which overtly are not inconsistent with Article 5(2), for example, the $\$ 20(2)$ of the German Allgemeine Gleichbehandlungsgesetr (AGG) ${ }^{56}$, can be maintained until 20 December 2012, but will not be able to be offered from 21 December 2012 onwards, where the "unisex" tariffs will be mandatory. This means that premiums charged before 20 December 2012 will have to be recalculated, which may result in general premium increases. ${ }^{57}$ The new premium tariffs will only be legal under EU law if they do not (overtly or indirectly) discriminate but only differentiate on the basis of accepted actuarial techniques. The Court of Justice does not seem to require, contrary to what was suggested by AG Kokott ${ }^{58}$ to readapt existing tariffs, premiums and benefits, even of contracts of long duration which violated the principle of non-discrimination. The "dynamic" reasoning of the Court clearly suggests that, despite doubts, the Member State exemption of Article 5(2) was perfectly legal during a period of five years, and only would lose its justifying force for tariffs based on sex-discrimination on 21 December 2012. Therefore, there is no retroactive effect of the Court's judgment on the existing tariffs which were used before that date ${ }^{59}$. Insurers will appreciate this solution, while clients may regret that they will not profit from the judgment, neither for the past, nor in all probability for the future. Non-discrimination comes at a price and is likely to be not a "consumer-friendly" measure because cautious women drivers will have to subsidise their more risky male drivers, and male insured persons will have to pay for additional costs of women's medical treatment and longer life expectancy.

54 See $\int 30$.

$55 \int 33$.

56 Concerning the constitutionality of the exception under German law see RÖDI, F., in Rust/Falke (eds.), Kommentar zum AGG, $\ 20, \int 37$ arguing that a differentation concerning insurance tariffs are justified by objective reasons (sachlicher Grund). This argument can no longer be maintained due to the priority of EU law.

57 This is feared by many observers, see the article in Süddeutsche Zeitung of 19.3.2011, p. 32.

$58 \int 81$ of her opinion.

59 Against TOBLER, CMLRev 2011, at p. 2057. For a restrictive interpretation of the concept of," "new contracts" in Art. 5 (1) of Dir. 2004/114 see the Commission guidelines of 13.1.2012, [2012] OJ C 11/1, excluding automatic extensions, unilateral premium adjustments, follow-on policies pre-agreed before 21.12.2012 (no. 13). 


\section{b. A possible critique of the judgment: too much "equal treatment", too little autonomy left?}

The judgment obviously has been subject to the fundamental critique that the Court has sacrificed private autonomy (including calculation of premiums by insurers according to their business models) on the "altar of non-discrimination", despite the assurance in Article 3(2) of Directive 2004/113 that the measure will not prejudice the freedom of choosing a contractual partner, with a somewhat obscure exception "so long as an individual's choice is not based on that person's sex" ${ }^{60}$ Indeed, there seem to be three fundamental weaknesses of the Court's argument. First, the yardstick for measuring "equal treatment" is a formal one as written into Directive 2004/113, not a substantive one, based on a value judgment inherent in the concept of "discrimination" itself. Thinking this argument to its final consequences, the EU legislator should not even be entitled to impose a transition period, unlike the grace period of 5 years allowed by the Court to the EU legislator. Secondly, as pointed out by Effer-Uhe ${ }^{61}$ the Court invalidated the optional provision of Article 5(2) of Directive 2004/113 even though it was the very point which enabled a unanimous adoption of the Directive, as required by Article 19 TFEU (then Article 13 EC). It could be argued that by invalidating the provision the Court rendered the requirement of "unanimity" nugatory. Personally, I find this argument unconvincing because there can be no exemption from the fundamental rights control by the Court for optional EU-law provisions whose application would allow Member States to maintain "unconstitutional" provisions.

Thirdly, while according to Article 23 of the Charter "equality between men and women must be ensured in all areas (italics NR)", it is also subject to proportionate limitations by law under Article 52(1) of the Charter. As Lüttringhaus ${ }^{62}$ observed, the Court did not seriously consider possible justifications of "discriminations" - or rather differentiations - between men and women in calculating insurance tariffs. Following the detailed socio-legal argumentation of AG Kokott, such a strict proportionality test could have resulted in condemning higher tariffs for men in third party liability car insurance, and for women in health insurance because of fragmented and inconclusive statistical evidence not taking into account different risk profiles and life styles of insured persons, where sex is not any more a determining factor. But bonus/malus schemes could have been found to be a more flexible and therefore a more proportionate instrument to avoid the "moral hazard" on part of the insured persons. Under these circumstances, sex was a rather "crude" and therefore discriminatory method of risk determination. On the other hand, it is arguable that premiums for life insurance should be allowed to be calculated differently for the simple fact that the average life expectancy in the

\footnotetext{
60 J. Lüttringhaus, Europaweit Unisex-Tarife für Versicherungen, EuZW 2011, 296.

${ }_{61}$ Supra note 46 at pp. 113. Concerning the compromise version of Art. 5 (2) see Cousy, supra note 42 at pp. 99.

62 At p. 298.
} 
EU of women is longer than that of men, and therefore women pay more and for a longer time before they start enjoying the benefits. Reference to publicly available statistics determining different risk profiles of men and women has nothing to do with "discrimination" or "unequal treatment", but simply takes differences in life expectancies at their face value to avoid that men with an average shorter life expectancy subsidise longer living women. It follows that it is possible to argue that the Court of Justice failed to carry out the necessary balancing between "party autonomy" and "equal treatment" in the insurance market, which is a basic pillar of pluralism in private law as understood in this context.

\section{Non-discrimination of access to and treatment in services of general economic interest and in network services: limited autonomy}

Services of general economic interest, like communication, energy, transport, have only recently come within the scope of Union law, in line with trends of deregulation and privatisation affecting these sectors. In the 'old days' these services were highly regulated by public law, where the principles of non-discrimination could be applied without dogmatic problems relating to party autonomy. The new regime is, by contrast, more concerned with competition and choice. Accordingly, it has had to develop standards of its own, in particular by transposing (somewhat hesitantly) the idea of solidarity alongside the more economic and competitionorientated understanding of public services, and thus including questions of consumer (or rather user) access and equality. ${ }^{63}$ The EU Commission has proposed including these services in its work on consumer protection. ${ }^{64}$ Because the provision of these services requires conclusion of a contact, EU law which regulates services of general economic interest could be seen as belonging also to 'private law' and concerning horizontal situations, albeit extensively regulated by economic law.

The most important elements of EU regulation of services of general economic interest have been, on the one hand, the internal market approach, and on the other, the so-called 'universal service obligation' of providers. ${ }^{65}$ Their impact on free choice in access to services and on obligations of non-discriminatory treatment without distinguishing between consumers in the traditional sense and other users. For example, under the Universal Services Directive 2002/22/EC ${ }^{66}$ and the revised

63 ROSS, M., Promoting Solidarity: From Public Service to a European Model of Competition? CMLRev. 2007, 1057 at 1070 insisting on the applicability of the general norm of Article 16 EC (now Art. 14 TFEU).

${ }^{64}$ Consumer Policy strategy, COM (2002) \$ 3.1.5; also COM (2007) 99 at 12: EU Consumer Policy Strategy 2007-2013.

65 ROTT, P., Consumers and Services of General Interest: Is EC Consumer Law the Future?, JCP 2007, 53; REICH, Crisis of Future of European Consumer Law? Yearbook of Consumer law, 2008, 2009, 3 (20); MICKLITZ, H. W. The Visible Hand of European Regulatory Private Law, YEL 2009, 3 at p. 22 ff.

66 Directive 2002/22/EC of the European Parliament and the Council of 2002 on universal service and user's rights relating to electronic communications, networks and services (Universal Services Directive) [2002] OJ L 108/51, amended by Directive 2009/136/EC of 19.12.2009, [2009] OJ L 337. 
Electricity Directive 2003/54/EC ${ }^{67}$ 'household customers' should not be prevented from switching to another provider through direct or indirect impediments. ${ }^{68}$ On 17 July 2009 the European Parliament and the Council adopted Directive 2009/72/ EC concerning common rules for the internal market of electricity and repealing Directive 2003/54/EC ${ }^{69}$. Article 3(7) of the Directive contains general obligations of Member States to protect final, in particular vulnerable, consumers in markets with universal service obligations:

\footnotetext{
"In this context, each Member State shall dedine the concept of vulnerable customer which may refer to energy poverty and, inter alia, to the prohibition of disconnection of electricity to such customer in critical times."
}

These provisions try to improve the position of - in particular vulnerable - consumers against the old directive mentioned above, although only halfheartedly. They are too unspecific to take direct effect. Much more specific are the transparency requirements of Annex I concerning the contracting with the universal service supplier. These principles are extended to other network services like banking. Access rules are contained in the Directive 2007/64/EC of 13 December 2007 on payment services in the internal market ${ }^{70}$. Article 28 contains detailed provisions protecting the "recipient of services" against discrimination, not limited to the traditional consumer, but also including commercial clients. This right of "access" to payment services without discrimination seems to have the effect of transforming payment systems in the EU, despite their heterogeneity, into a "service of general economic interest" based on private law (without, however, a "universal service obligation"), and subjected to special rules which go beyond the traditional concepts of private autonomy and freedom of contract.

Quite suprisingly, the impact of this encroachment of regulation on private law has hardly been discussed so far. The non-discrimination principle has a special role to play in this context and yet the area seems to be, as Micklitz ${ }^{71}$ correctly observes, a blind spot in the eyes of private law scholars, who believe that this highly regulated sector still follows the principle of party autonomy. As Micklitz writes:

67 Directive 2003/54/EC of the European Parliament and the Council of 26 June 2003 concerning Common Rules for the Internal Market for Electricity, [2003] OJ L 176, 32.

68 ROTT at 56; MICKLITZ, The Concept of Competitive Contract Law, PennStateLJ 2005, 549 at p. 576; WILLET, Chr., General Clauses on Fairness and the Promotion of Values important in Services of General Interest, in TWIGG-FLESNER et al (eds.), The Yearbook of Consumer Law 2007, Ashgate 2008,67 at $95-100$.

69 [2009] OJ L 211/55.

70 [2007] OJ L 319; comment St. Grundmann/G. Hoffmann, ERCL 2010, 467 at p. 472.

71 MICKLITZ, H. W. The Visible Hand of European Regulatory Private Law, YEL 2009 at p. 23.

Revista Mestrado em Direito, Osasco, ano 13, n. 1, p. 113-142 


\begin{abstract}
"The network law develops, within the boundaries of universal services, concepts and devices whose reach must be tested with regard to their potential for general application beyond the narrow subject matter. Just one example may be mentioned: despite privatisation, network industries have to guarantee the accessibility and the affordability of their services. What is at stake here is the obligation to contract (Kontrahierungszwang) and the duty to continue delivery even in cases of late payment."
\end{abstract}

As a result of these developments, the principle of non-discrimination is "creeping" into European contract law. It has the potential of expanding its scope of application beyond the areas and grounds recognised so far in EU law, and briefly mentioned in this paper. Its impact on citizens and consumers may however be double-headed, as the recent Tests Achats case shows. Equal treatment comes at a cost. Somebody has to bear the financial consequences of the principle's expansion!

\title{
7. Effective remedies and sanctions in cases of discrimination
}

Despite the limitations of the non-discrimination principle in private law matters, discussed for example by Basedow ${ }^{72}$, the principle is not and should not be conceptualised as "an incomplete legal norm". On the contrary, Member States are under an obligation to sanction non-justified discriminations in private law relations, whether or not they provide for private law remedies ${ }^{73}$. Private law, as insisted on by Steindorff, ${ }^{74}$ has a Sanktionsaufgabe - the task of providing sanctions. They must be effective, the requirement highlighted by AG Poiares Maduro in his opinion of 12 March 2008 in the Belgian Feryn case ${ }^{75}$. The case concerned ethnic discrimination by a producer and installer of "up-and-over doors", who publicly declared he did not employ immigrants (in the circumstance mostly persons of Arabic origin) to attract clients who in the fear of theft would be unwilling to employ the defendant. AG Poiares Maduro pointed out that: ${ }^{76}$

72 BASEDOW, J. Grundsatz der Nichtdiskriminierung, Zeitschrift für Europäisches Privatrecht (ZEuP) 2008, at 240.

73 REICH, The interrelation between rights and duties in EU Law: Reflections on the state of liability law in the multilevel governance system of the Union - Is there a need for a more coherent approach in European private law?, in: YEL, 2010, 112 at pp. 141.

74 STEINDORFF, E, EWG-Vertrag und Privatrecht, 1996, at $303 \mathrm{ff}$.

75 Case C-54/07 Centrum voor gelijkheid van kansen en voor racismebestrijding (CGKR) v Firma Feryn NV, [2008] ECR I-5187; Reich, EuZW 2008, 229; Lüttringhaus supra note 4 at pp. 365.

76 SS 27-29. 
"On the issue of sanctions, Article 15 of the Directive (2000/43, NR) provides that 'Member States shall lay down the rules on sanctions applicable to infringements of the national provisions adopted pursuant to this Directive and shall take all measures necessary to ensure that they are applied'. The sanctions, which may comprise the payment of compensation to the victim, must be effective, proportionate and dissuasive...' Moreover... national courts have a duty to take all appropriate measures to ensure fulfilment of the Member States' obligation to achieve the result envisaged by the Directive. It is for the referring court to determine, in accordance with the relevant rules of domestic law, which remedy would be appropriate in the circumstances of the present case. However, .... purely token sanctions are not sufficiently dissuasive to enforce the prohibition of discrimination. Therefore, it would seem that a court order prohibiting such behaviour would constitute a more appropriate remedy. In sum, if the national court finds that there has been a breach of the principle of equal treatment, it must grant remedies that are effective, proportionate and dissuasive".

In the judgment of 10 July 2008 the Court largely followed AG Poiares Maduro's opinion, while allowing the employer to prove that in his actual recruitment policy he did not discriminate (a somewhat problematic defence, since it does not eliminate the effect of his public statements which were clearly discriminatory). With regard to remedies, the Court allowed the national jurisdiction a wide range of alternatives, provided that the principles of effectiveness, proportionality and dissuasiveness were respected: $:^{77}$

"If it appears appropriate to the situation at issue in the main proceedings, those sanctions may, where necessary, include a finding of discrimination by the court or the competent administrative authority in conjunction with an adequate level of publicity, the cost of which is to be borne by the defendant. They may also take the form of a prohibitory injunction, in accordance with the rules of national law, ordering the employer to cease the discriminatory practice, and, where appropriate, a fine. They may, moreover, take the form of the award of damages to the body bringing the proceedings".

This judgment follows the earlier approach of the Court, adopted ever since von Colson, ${ }^{78}$ where the Court of Justice has insisted on the principle of effectiveness in the provision of a remedy: ${ }^{79}$

[Compensation must] be such as to guarantee real and effective judicial protection, ... have a real deterrent effect on the employer [and] must in any event be adequate in relation to the damages sustained ... purely nominal [compensation] eg the reimbursement of expenses incurred by them [the candidates] in submitting their application, would not satisfy the requirement of an effective transposition of the directive.

$77 \int 39$.

78 Case 14/83 Von Colson and Kamann v Land Nordrbein-Westfalen [1984] ECR 1891.

$79 \iint 23-24$. 
In this still very important judgment, the Court rejected a merely symbolic compensation as incompatible with the principle of effectiveness. It is not quite clear on what legal principle the Court based its principle of full compensation since the Directive was silent on this point, especially as the Court held at the same time that Mrs von Colson did not have the right to a contract. In this light it would be difficult to explain the claimant's right to full compensation on the basis of a contract theory. In my opinion, the damage which the Court strove to remedy by its ruling was primarily 'moral'. This raises the question whether EU law should require non-material damages to be awarded more generally for breaches of EU sex discrimination prohibitions. The principle of compensation for non-material damage found its first overt recognition in Leitner ${ }^{80}$, a case involving a claim for lost holidays. This judgement could be taken to apply to all types of liability based on EU law, which would bring private liability in line with the case-law on Article 288(2) EC (now Article 340 TFEU) concerning Community/Union liability with regard to non-material damage suffered by employees due to 'sufficiently serious breaches' of obligations towards them. ${ }^{81}$ In this way persons who have been subjected to discriminatory treatment should not be treated in EU law any different from frustrated holiday tourists. ${ }^{82}$ In my opinion, a constitutional argument could be put forward to allow for compensation of non-material damage also in discrimination cases; since discrimination is an act violating fundamental personality rights, ${ }^{83}$ and it has been expressly included in the Charter of Fundamental Rights (Articles 21 and 23), it must be adequately protected. Moreover, the principle of compensation for moral damage in cases of discrimination improves the 'deterrent effect' of the compensatory remedy and on this ground can be easily regarded as necessary under the existing doctrines of EU law. ${ }^{84}$

As for "collective remedies", which are sought by NGOs (associations, organisations or other legal entities, which have, in accordance with national law, a legitimate interest in ensuring that the provisions [on non-discrimination] are complied with), are foreseen in Article 7(2) of Directive 2000/43 and Article 8(3) of Directive 2004/113. However, these NGOs may only bring actions in limited circumstances, exclusively in order to support individuals having suffered from discrimination and such actions require their approval. Injunctions, unlike in consumer cases, are not expressly foreseen; a regrettable lacuna of non-discrimination law. However, since the Directive imposes only a minimum requirement also in the area of remedial protection, Member states may go beyond what is envisaged in it,

Case C-168/00 Leitner v TUI Deutschland [2002] ECR I-2631.

Case C-308/87 Grifoni II [1994] ECR I-341 \37; Case T-59/92 Caronna [1993] ECR II-1129 \106.

82 I have already argued elsewhere that the case-law of the Court of Justice in its insistence on the 'effectiveness' argument has developed a rule under which compensation for non-material damage is required for violations of EU rights. Supra note 72 at pp. 148.

83 A. Masselot, The State of Gender Equality Law in the EU, ELJ, 2007, 152 at p. 154.

84 REICH, N, Diskriminierungsverbote im Gemeinschaftsrecht, in: Jahrbuch Junger Zivilrechtswissenschaftler 2005, 23-4. 
and allow "independent" actions and injunctions by NOGs, a possibility regrettably not taken up by German law.

\section{Conclusion: From an "individualistic" concept of discrimination to an understanding of its collective dimension}

The mainstream discussion in private law has been concentrating unilaterally on the tension between a general principle of private autonomy as the fundamental pillar of private law in the EU, on the one hand, and the principle of equal treatment, understood as a rather limited exception restricted to such grounds as sex, ethnic origin, nationality (the personal characteristics), and perhaps extended also onto such characteristics as age, disability, or sexual orientation. Some German authors have, however, been more radical. Säcker criticises non-discrimination law as "Tugendrepublik der neuen Jakobiner" ("Virtue-republic of the new Jacobins"). ${ }^{85}$ Repgen, on the other hand, hears in the recent developments "the death bell of private law" (Totenglocke des Privatrechts). ${ }^{86}$ There seems to be an agreement among the cited authors that, as a general rule, private autonomy should prevail over "equal treatment" in most conflict situations in private law.

The discussion prevalent in private law scholarship does not seem adequately to acknowledge that new tendencies are emerging and they will necessitate judicial recognition. The developments in EU law described in this chapter explicitly impose equal treatment obligations on contract partners, in the context of employment relations and in the of supply of goods or services available to the public, like insurance, and services of general economic interest, like energy, transport, communication, and payment services. However, what seems to be underdeveloped in the discussion so far is the collective effect of discrimination, and the corresponding collective perspective of the law of non-discrimination. This narrow individual perspective of the current debate is to some extent provoked by the characteristics of the cases referred to the Court of Justice. They usually concern a dispute between an individual allegedly discriminated against because of its sex, nationality, race, now also age, disability, sexual orientation, in employment or a business-consumer relation, on the one hand, and an employer, a business, or a professional, on the other. The very structure of the reference proceedings before the Court allows only a limited input from organisations representing the collective interests of citizens, NGOs, trade associations or labour unions ${ }^{87}$. These

${ }^{5}$ SÄCKER,,Vernunft statt Freiheit““ - Die Tugenrepublik der neuen Jakobiner, ZRP 2002, 286.

86 REPGEN, Anti-Diskriminierung - die Totenglocke des Privatrechts läutet, in: Isensee (Hrsg.), Vertragsfreiheit und Diskriminierung, 2007, p. 11; a similar critical view has also been taken by LOBINGER, Vertragsfreiheti und Diskriminierungsverbote, in Isensee pp. 99.

87 The deficiencies in public interest litigation before European Courts had already been pointed out in a publication edited by MICKLITZ, H./ REICH, of 1996; see in particular my paper at pp. 8 pointing to the possibities and even more the limits of EC procedural law for genuine public interest litigation. 
organisations have the ability to present arguments before the Court of Justice only when the original litigation before the national court had been initiated by them, like in the Belgian Feryn and Test Achats cases. ${ }^{88}$

In his seminal publication Micklitz ${ }^{89}$ has shown that many English employment discrimination cases, though couched in the form of an individual complaint, in reality were public interest litigations sponsored by a special government office (the Equal Opportunities Commission), by other NGOs or, less frequently, by trade unions. A similar study does not seem exist to my knowledge with respect to other countries. ${ }^{90}$ The non-discrimination directives themselves contain provisions on public interest litigation, however they are rather weak, leave details to Member State laws, and subject proceedings the requirement of approval by injured persons, thus still taking an individualistic starting point.

The collective dimension of EU non-discrimination law has already been pointed out before me by other authors. Collins ${ }^{91}$ writes:

"A second strand of justification, however, should interest us more, because it is more directly aimed at explaining the aim of antidiscrimination laws. This element of the official discourse refers to the notion of social inclusion as a key justification for anti-discrimination law (italics NR)." ${ }^{, 92}$

The German author Lauber ${ }^{93}$ argues for a human rights approach to discrimination law, including elements of both individual and group justice. She points out that "distributive, group-oriented measures have their place in contract law and are not in opposition to it". ${ }^{44}$ She writes:

\footnotetext{
"Both contractual freedom and the right to non-discrimination enjoy the position of fundamental rights, but contractual freedom should be understood as a substantive concept with limits, which only in certain aspects must be regarded as a general principle, while the equal treatment principle is expressly protected by the Charter of Fundamental Rights" (translation NR).
}

In a recent paper on the 'Social, Political and Cultural Dimension of EU Private Law, ${ }^{95}$ based on earlier reflections by Wilhelmsson, ${ }^{96} \mathrm{I}$ argued for a welfarist

88 Supra notes 73/44; Lüttringhaus supra note 4 at p. 400.

89 MICKLITZ, The Policies of Judicial Co-operation in the EU, 2005, pp. 116

90 The Ius Commune Casebook by D.SCHIEK, D/WADDINGTON, L./BELL,M., Non-Discrimination law, 2007, contains a chapter on "sanctions", pp. 871, but does not seem to pay specific attention to private litigation for enforcement.

91 COLLINS, Discrimination, Equality, and Social Inclusion, ModLRev 2003, 16.

92 At p. 21.

93 LAUBER, Paritätische Vertragsfreiheit durch reflexiven Diskriminierungsschutz, 2009.

94 LAUBER, Paritätische Vertragsfreiheit durch reflexiven Diskriminierungsschutz, 2009, pp. 234.

95 Cited supra*.

96 WILHELMSSON, T, Varieties of Welfarism of in European Contract Law, ELJ 2004, 172. 
objective in non-discrimination law which is concerned with "regulation aimed at redistributing benefits in favour of the disadvantaged within a group of contract parties in similar situations", even though it seems to be "only emerging in the case law of the ECJ, in particular with regard to effective enforcement". ${ }^{97}$ This collective, welfarist element in non-discrimination law certainly needs a more thorough examination, which lies beyond the remit of this chapter. It is true that this collective dimension of non-discrimination law may conflict with a purely individualistic concept of contractual freedom which is still the dominant position in German (and perhaps also English) private law. However, the Charter of Fundamental rights may indeed require a reorientation of this view. In order to preserve the autonomy of private law and the role of its structural principles I suggest that the following distinction should be introduced. Direct discriminations based on sex, race, and other incriminated factors, even if seemingly justified by the principle of contractual freedom, should be seen as violating an individual's rights under Articles 21 and 23 of the Charter of Fundamental Rights, expressed in specific EU acts, and must be sanctioned by effective remedies as developed in the case law of the Court of Justice. In particular, compensation of non-pecuniary damages should be demanded as a matter of EU law. A recent example of a boundary case which would still fall within this category is Coleman ${ }^{98}$, which extended the discrimination concept against disabled persons onto those discriminated "by association". The case concerned a female employee, whose child was born handicapped, who allegedly was harassed into a "constructive dismissal" by her employer, an English law firm. Similar cases in consumer contracts continue to be rare, although the study done by Schiek done on German practices has reported some instances of racist treatment in leisure activities, discriminatory credit scoring by banks and rejections of disabled persons in tourism. ${ }^{99}$ Indirect discriminations, on the other hand, which is likely to relate more directly to a collective dimension of discrimination, should still be regarded as prima facie violating fundamental rights, but it should necessarily be balanced against other legitimate interests under the proportionality test. These interests should include the freedom of contract. Unjustified indirect discrimination should be combated by adequate sanctions. If an individualistic remedy, like compensation, is used by national law, it must fulfil the von Colson criteria described above, including that of a "real deterrent effect". Private law is used - some incorrectly say "abused" - as a means of public interest enforcement and should be shaped by national law also with a view of fulfilling this function. Standing of anti-discrimination NGOs should be extended beyond the limits of the existing equal treatment directives and should not require approval of the injured persons.

\footnotetext{
At pp. $58,77$.

Case C-303/06 S. Coleman v Attridge Law et al [2008] ECR I-5603; the case was settled out of court!

SCHIEK, D., Differenzierte Gerechtigkeit, 2000. at pp. 198. SCHIEK's study concerned with discriminations in consumer relations in German insurance, banking, recreation, and tourism businesses, and was written before the enactment of the relevant EU directives.
} 


\section{References}

BASEDOW, J. Mangold Audiolux und die allgemeinen Grundsätze des europäischen Privatrechts, in: FS Klaus Hopt, 2010

BASEDOW, J. The Court of Justice and Private Law, in: ERevPrL, 2010

BASEDOW, J. Grundsatz der Nichtdiskriminierung, in: ZEuP, 2008.

BOROWSKY, in: MEYER, J., Kommentar zur Charta, 3rd e-book ed. 2011

COLLINS, Discrimination, Equality, and Social Inclusion, in: ModLRev 2003

COUSY, H. Discrimination in Insurance Law, in: SCHULZE (ed.), Non-discrimination in European Private Law, 2011

CREMER, W., Grundrechtsverpflichtete und Grundrechtsdimensionen nach der Charta der Grundrechte in der EU, in: EuGRZ 2011

D. Effer-Uhe, Gleichbehandlung in Versicherungsverträgen, in: SCHULZE (ed.), Non-discrimination in European Private Law, 2011

DOUGAN, M., In Defence of Mangold?, in: ARNULL ET ALL, A Constitutional Order of States - Essays in Honour of A. Dashwood

ELSMORE, M. \& STARUP. P., Union Citizenship - Background, Jurisprudence, and Perspective, in: YEL 2007

HESSELINK, If You Don't Like Our Principles We Have Others, in: BROWNSWORD ET AL (eds.), The Foundations of European Private Law, 2011.

HESSELINK, M., The general principles of civil law: Their nature, role and legitimacy

KARPENSTEIN, U., Harmonie durch die Hintertür? Geschlechtsspezifisch kalkulierte Versicherungstarife und das Diskriminierungsverbot, in: EuZW 2010

KOSTA, V. Internal Market Legislation and the Private Law of the Member States - The Impact of Fundamental Rights, in: ERCL 2010

LAGARDE, P., Droit international privé, in: SCHULZE/SCHULZE/-NÖLKE (eds.), European Private Law - Current Status and Perspectives, 2011

LAUBER, Paritätische Vertragsfreiheit durch reflexiven Diskriminierungsschutz, 2009

LENAERTS, K/ GUTIÈRREZ-FONS,J., The Constitutional Allocation of Powers and General Principles of EU Law, in: CMLRev 2010

LOBINGER, Vertragsfreiheti und Diskriminierungsverbote, in: Isensee (Hrsg.), Vertragsfreiheit und Diskriminierung, 2007

LÜTTRINGHAUS, J., Europaweit Unisex-Tarife für Versicherungen, in: EuZW 2011

MASSELOT, A. The State of Gender Equality Law in the EU, in: ELJ, 2007

MAZIÈRE, P., Le principe d'égalité en droit privé, 2003

METZGER, A. Extra legem, intra ius: Allgemeine Rechtsgrundsätze im Europäischen Privatrecht, 2009 
REICH, EuZW, 2006, 2007

MICKLITZ (ed.), The Many Concepts of Social Justice in European Private Law, 2011

MICKLITZ, H. W. The Visible Hand of European Regulatory Private Law, in: YEL 2009

MICKLITZ, The Concept of Competitive Contract Law, in: PennStateLJ 2005

MICKLITZ, The Policies of Judicial Co-operation in the EU, 2005

PAYANDH, CMLRev 2011,9.

PURNHAGEN, K., EuR 2011

REICH et al. Understanding EU Internal Market Law, 3rd ed. 2012

REICH, The public/private divide in European law, in: CAFAGGI/MICKLITZ (ed.), After the Common Frame of Reference, 2010.

REICH, Balancing in Private Law and the Imperatives of the Public Interest, in BROWNSWORD ET AL (eds.), The Foundations of European Private Law, 2011.

REICH, Crisis of Future of European Consumer Law? in: Yearbook of Consumer law, 2008, 2009, 3 (20)

REICH, EuZW 2010

REICH, N, Diskriminierungsverbote im Gemeinschaftsrecht, in: Jahrbuch Junger Zivilrechtswissenschaftler 2005

REICH, N. Some Thoughts after the,,Test Achats“Judgment, in: EJRR 2011

REPGEN, Anti-Diskriminierung - die Totenglocke des Privatrechts läutet, in: Isensee (Hrsg.), Vertragsfreiheit und Diskriminierung, 2007

RIESENHUBER, K., Das Verbot der Diskriminierung aufgrund der Rasse und der ethnischen Herkunft sowie aufgrund des Geschlechts beim Zugang zu und der Versorgung mit Gütern und Dienstleistungen, in: Leible/S chlachter, Diskriminierungsschutz durch Privatrecht, 2007

RÖDI, F., in Rust/Falke (eds.), Kommentar zum AGG

ROSS, M., Promoting Solidarity: From Public Service to a European Model of Competition?, in: CMLRev. 2007

ROTT, P., Consumers and Services of General Interest: Is EC Consumer Law the Future?, in: JCP 2007

SÄCKER, „Vernunft statt Freiheit“ - Die Tugenrepublik der neuen Jakobiner, in: ZRP 2002

SCHEREIER, M. Das Allgemeine Gleichbehandlungsgesetz - wirklich ein Eingriff in die Vertragsfreiheit?, in: KRITJ 2007

SCHIEK, D., Differenzierte Gerechtigkeit, 2000.

SCHIEK, D et al. (eds.), Non-discrimination law, 2007

SCHIEK, D/ WADDINGTON, L./BELL,M., Non-Discrimination law, 2007

SPAVENTA, E., The Horizontal Application of Fundamental Rights as General Principles of Union Law, in: ARNULL et al. (eds.), A Constitutional Order of States - Essays in Honour of A. Dashwood, 2011

Revista Mestrado em Direito, Osasco, ano 13, n. 1, p. 113-142 
St. GRUNDMANN/HOFFMANN, G., in: ERCL 2010.

STEINDORFF, E, EWG-Vertrag und Privatrecht, 1996

TOBLER, Chr. CMLRev 2011

TRIDIMAS, T., The General Principles of EU Law, $2^{\text {nd }}$ ed.2006

VANDENBERGHE, A.-S., Proposal for a new Directive on non-discrimination, in: ZEuP 2011

WILHELMSSON, T, Varieties of Welfarism of in European Contract Law, in: ELJ 2004

WILLET, Chr., General Clauses on Fairness and the Promotion of Values important in Services of General Interest, in TWIGG-FLESNER et al (eds.), The Yearbook of Consumer Law 2007, Ashgate 2008

\section{Norbert Reich}

Emeritus Professor, University of Bremen, Faculty of Law, e-mail n.reich1@gmx.net. The paper continues earlier reflections in: REICH, N. The public/private divide in European law, in: CAFAGGI/ MICKLITZ (ed.), After the Common Frame of Reference, 2010, pp. 56; same: "The Social, Political and Cultural Dimension of EU Private Law", in: R. SCHULZE (ed.), European Private Law - Current Status and Perspectives 2011, pp. 57; same: "Pluralism and Private Law in the Union", in: L. NIGLIA (ed.), Pluralism and European Private Law, 2013, pp. 73; same, The Impact of the Non-Discrimination Principle on Private Autonomy, in: D. Leczykiewicz/St. Weatherill (eds.), The Involvement of EU Law in Private Relationships, 2013, pp. 252. 